\title{
Diversity and distribution of medicinal plants in the Universitas Sumatera Utara Arboretum of Deli Serdang, North Sumatra, Indonesia
}

\author{
RAHMAWATY ${ }^{1, \boldsymbol{v}}$, J.B. SAMOSIR ${ }^{1}$, R. BATUBARA ${ }^{1}$, A. RAUF ${ }^{2}$ \\ ${ }^{1}$ Departement of Forest Management, Faculty of Forestry, Universitas Sumatera Utara. Jl. Tridharma Ujung No.1, Kampus USU Padang Bulan, \\ Medan 20155, North Sumatra, Indonesia. Tel./Fax.: Tel.: +62-61-8220605, Fax.: +62-61-8201920, `email: rahmawaty@usu.ac.id \\ ${ }^{2}$ Faculty of Agriculture, Universitas Sumatera Utara. J1. Dr. A. Sofian No.3, Kampus USU Padang Bulan, Medan 20155, North Sumatra, Indonesia.
}

Manuscript received: 16 February 2019. Revision accepted: 29 April 2019.

\begin{abstract}
Rahmawaty, Samosir JB, Batubara R, Rauf A. 2019. Diversity and distribution of medicinal plants in the Universitas Sumatera Utara Arboretum of Deli Serdang, North Sumatra, Indonesia. Biodiversitas 20: 1457-1465. The plants found in Universitas Sumatera Utara (USU) Arboretum has the potential to be utilized by the local community to meet their food and medicinal needs. The objectives of this study were to calculate the species diversity, to find out the various parts of plants utilized for medicinal purposes and to map the distribution of medicinal plants in the arboretum. Survey and interview methods were used to collect data. The species diversity was determined using Shannon-Wiener index. Geographic Information System (GIS) was used to map the distribution of medicinal plants. The results showed that there were 17 species of medicinal herbs, 21 species of trees and 12 species of poles in the arboretum. The diversity was classified as moderate based on the calculated value. The most predominant part of plants utilized for medicinal purposes were leaves. The distribution of medicinal plants was mostly clustered and uneven. The condition indicates still there is scope for additional planting of medicinal species to increase the diversity of species, especially in the western and the northern part of the arboretum.
\end{abstract}

Keywords: Community, diversity, GIS, medicinal plants

\section{INTRODUCTION}

Indonesia has mega-diversity of natural resources. One of the most important biodiversity is of medicinal plants. Medical experts known as physicians make medicinal preparations from herbal raw materials collected from the forest. Traditional medicines and pharmaceuticals derived from forests currently play an important role in global health care. Musinguzi et al. (2017) reported that medicinal and aromatic plants represent the largest number of plants collected from natural forests. There are several medicinal herbs that have been known to the people of Indonesia since very long, more than even hundreds of years. According to Nugroho (2010), it is estimated that Indonesia's forests are the repository of as many as 30,000 types of potential medicinal plants, of which 940 species have already been declared as medicinal and around $78 \%$ of these species are obtained still through direct extraction from the forest.

According to Zuhud et al. (1994) and Zuhud and Hikmat (2009), the medicinal plants are classified into 3 categories, namely traditional medicinal plants, modern medicinal plants, and potential medicinal plants. Traditional medicinal plants are known already or believed to have medicinal properties and have been used as raw materials for traditional medicines. Modern medicinal plants are medicinal plants that have been scientifically proven to contain bioactive compounds/ingredients that have medicinal properties and their use can be medically accountable. Potential medicinal plants are suspected to be containing bioactive compounds/ingredients that are medicinally efficacious but have not yet proven to be used as ingredients of traditional medicine (Zuhud and Hikmat 2009).

Medicinal plants can be found in several places, including community lands, either planted or grown wild. According to Mashayekhan et al. (2016), wild plants are vitally important in supporting livelihoods for millions of people around the world. Current World trade volume of medicinal plants is more than 43 billion dollars and in 2050, has been predicted to reach to 5 trillion dollars. Many studies also have been reported about medicinal plants growing in different places. For instance, Chowdhury et al. (2009) conducted research on use of plants in the healthcare system of rural areas of southeastern Bangladesh. Singh et al. (2009) have studied diversity, indigenous uses and conservation prioritization of medicinal plants in Lahaul valley, India. Zuhud (2009) has studied the potential of Indonesian tropical forests as a support for natural medicines for protecting national health. Lense (2012) has studied wild plants as traditional medicines in Manokwari, West Papua, Indonesia. Silalahi et al. (2015) have reported the local knowledge of medicinal plants and diversity of medicinal plants in the Kabanjahe traditional market, North Sumatra, Indonesia. Deb et al. (2016) conducted research about ethnomedicinal plants used for herbal medication of jaundice by the indigenous community of Tripura, India. Noorul et al. (2016) have studied health benefits and pharmacology of Persea americana Mill. Musinguzi et al. (2017) studied the 
medicinal plants used in and around Kalinzu central forest reserve, Western Uganda. Zarta et al. (2018) work are on identification and evaluation of bioactivity in forest plants used for medicinal purposes by the Kutai community of East Kalimantan, Indonesia. Pandiangan et al. (2019) have studied diversity of medicinal plants and their uses by the Sanger Tribe of Sangihe Islands, North Sulawesi, Indonesia. Purba et al. (2016) reported the ethnomedicinal plants of the Batak Karo Peoples of Merdeka Subdistrict, North Sumatra, Indonesia.

Geographic Information System (GIS) technology is very helpful in research, including research related to medicinal plants and is the most popular tool used for studying the vegetation cover of a particular area. Several research studies have proved that GIS can be an impressive instrument for cataloging vegetation data obtained from ground surveys into mapping and analysis. For instance, Piri et al. (2019) have used GIS to assess the suitable areas for medicinal species of Astragalus. Shojaeic et al. (2018) conducted research on locating Astragalus hypsogeton Bunge using GIS. Biswas et al. (2017) have used GIS for identification and mapping of medicinal plants in India. Fathizad et al. (2017) have used GIS for exploring canola planting area in Meymeh-Zarinabad of Iran. Mashayekhan et al. (2016) have used GIS for mapping of medicinal plants in Iran. Al-Bakri (2011) has used GIS for analysis of spatial distribution of medicinal and herbaceous plants in arid and semi-arid zones in the North-West of Jordan.

One place that has the potential to find medicinal plants is Universitas Sumatera Utara (USU) Arboretum, located in Pancur Batu Sub District, Deli Serdang District, North Sumatra Province, Indonesia. There is no systematic documentation of species diversity, medicinal uses, parts used, distribution of plants, etc. about the medicinal plants of this location because such studies have not been conducted so far. Therefore, this study was undertaken with the objectives of documenting the distribution, species diversity index and useful parts of the medicinal plants of USU Arboretum.

\section{MATERIALS AND METHODS}

\section{Study area}

This research was conducted in USU Arboretum, Pancur Batu Sub District, Deli Serdang District, North Sumatra Province, Indonesia (Figure 1). The USU Arboretum has an area of 55 ha. Geographically, it is located between $98^{\circ} 39^{\prime} 12.90^{\prime \prime}$ to $99^{\circ} 10^{\prime} 2.83$ " east longitude and $3^{\circ} 32^{\prime} 7.00^{\prime \prime}$ to $3^{\circ} 34^{\prime} 8.06^{\prime \prime}$ north latitude. It is bordered by the Bekala River in the south and east and areas for other use (for campus facilities) in the west and north. The topography of the USU Arboretum was flat (slope was $0-8 \%$ ). The altitude was 120 meters above sea level. The soil type was dominated by Ultisol. In the beginning, the USU Arboretum construction was carried out in collaboration between USU and the Wampu Sei Ular Watershed Management Office, Ministry of Forestry, Republic of Indonesia. The USU Arboretum was built based on land rehabilitation by implementing an agroforestry system, where the trees planted were combined with corn and cassava to be used by the community around the USU Arboretum.
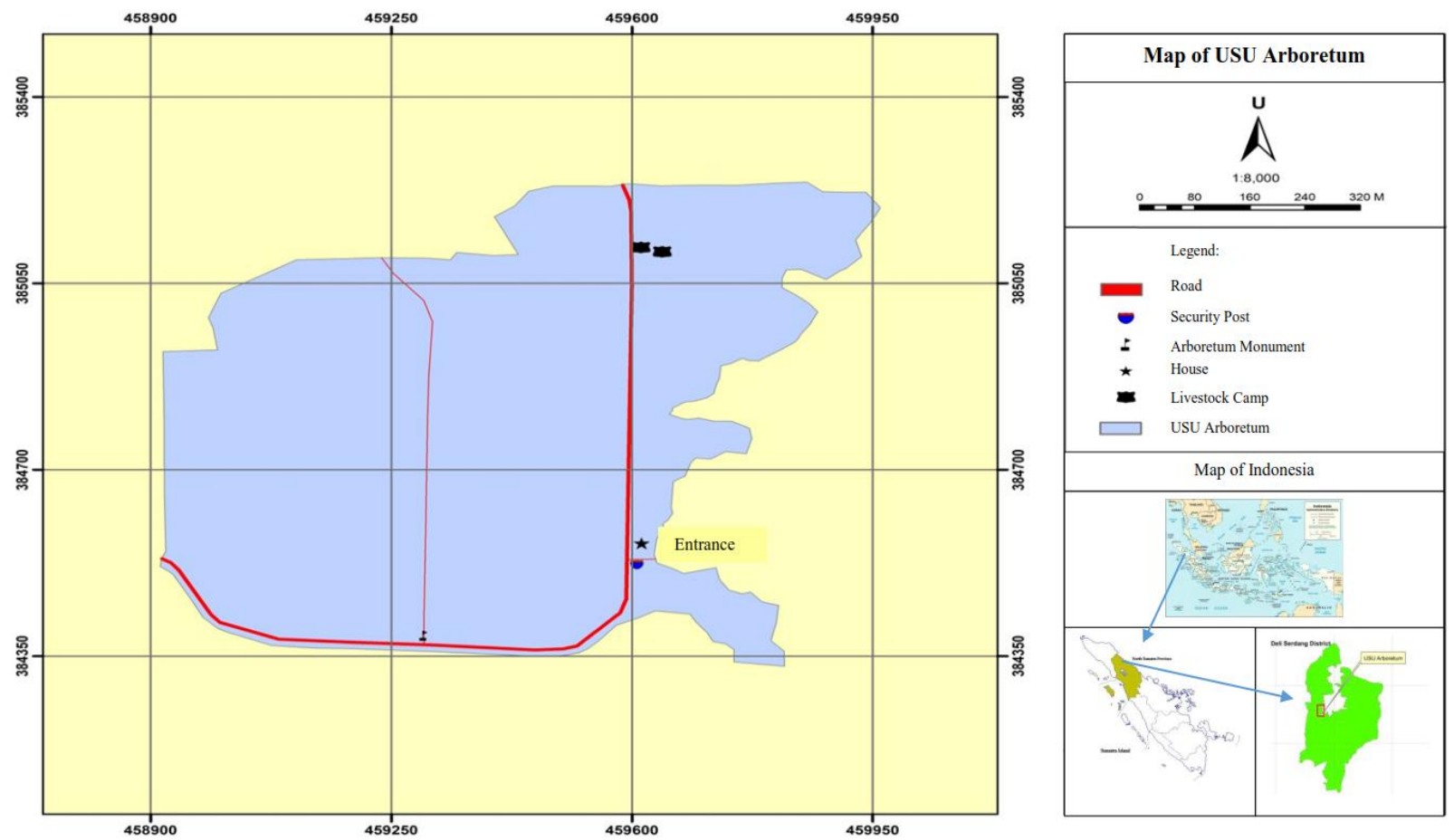

Figure 1. Map of research location in Universitas Sumatera Utara (USU) Arboretum, Pancur Batu Sub District, Deli Serdang District, North Sumatra Province, Indonesia 


\section{Data collection}

The survey method was used by making plots in the field. A global positioning system (GPS) was used to record the coordinate points of medicinal plants and a geographic information system (GIS) was used to map the distribution of the medicinal plants. Interview method was used to collect data regarding local names and the parts of herbs utilized for medicinal purposes. The two key informants were interviewed. They were male, comes from Karo Tribe, and work as traditional medicine experts and alternative medicine experts.

The total number of plot was 174. The size of each plot was $20 \times 20 \mathrm{~m}^{2}, 10 \times 10 \mathrm{~m}^{2}, 5 \times 5 \mathrm{~m}^{2}$, and $2 \times 2 \mathrm{~m}^{2}$, each for tree, pole, sapling, and seedling respectively. Tree is plant that has roots, stems, and canopy with a diameter of more than $20 \mathrm{~cm}$. Pole is a young tree with a diameter of 10 $\mathrm{cm}$ to $19 \mathrm{~cm}$. Sapling is regeneration with a height of more than $1.5 \mathrm{~m}$ up to a diameter of less than $10 \mathrm{~cm}$. Seedling is regeneration from sprouts to a height of less than $1.5 \mathrm{~m}$.

\section{Data analysis}

Knowledge and experience of local community were used to identify local names and the parts of herbs utilized for medicinal purposes, in the field. The same method has been used earlier by Silalahi et al. (2015) and Pandiangan et al. (2019). The plants were scientifically identified with the help of herbaria, photographs, and relevant botanical literature, such as Balai Pustaka (1980), Hutapea et al. (1994) and Dalimartha (2008).

The composition of stands was determined by the important value index (IVI). The IVI for tree consisted of the sum of the relative frequency (RF), the relative density (RDe) and the relative dominance (RDo). The composition of medicinal plants was also determined by the important value index (IVI). The IVI consisted of the sum of the relative frequency and the relative density. The mastery level of each species in the community was indicated by the IVI (Misra 1968; Sharma 2003). The diversity of species was calculated using the Shannon-Wiener diversity index (Shannon and Wiener 1963; Kent and Paddy 1992), as shown below:

$$
\begin{aligned}
& \mathrm{H}^{\prime}=-\Sigma(\mathrm{pi}) \text { Ln (pi) } \\
& \text { Where: } \\
& \mathrm{H}^{\prime}=\text { species diversity index } \\
& \mathrm{pi}=\mathrm{ni} / \mathrm{N} \\
& \mathrm{ni}=\mathrm{i} \text {-type important value } \\
& \mathrm{N}=\text { Number of important values of all types } \\
& \text { and the criteria used for are: } \\
& \mathrm{H}^{\prime}<1 \text {, diversity is relatively low } \\
& \mathrm{H}^{\prime} 1-3 \text {, diversity is classified as medium } \\
& \mathrm{H}^{\prime}>3 \text {, diversity is high }
\end{aligned}
$$

The distribution of medicinal plants was analyzed with the GIS by overlaying the GPS data and village map. The same method has been used by Rahmawaty et al. (2011),
Albakri et al. (2011), Rahmawaty et al (2015), Hamidy et al. (2016), Rahmawaty et al. (2017a), Rahmawaty et al. (2017b), Aliabad et al. (2018), Rahmawaty et al. (2018), Shojaeic et al. (2018) and Piri et al. (2019).

\section{RESULTS AND DISCUSSION}

\section{Diversity of medicinal plants}

Species diversity, numbers of trees of each species, important value index and species diversity index related to medicinal plants of USU Arboretum, Pancur Batu Sub District, Deli Serdang District, North Sumatra Province is presented in Table 1.

As shown in Table 1, Swietenia mahagoni (L.) Jacq. has the highest IVI (33.89\%), followed by Alstonia scholaris (L.) R.Br. (29.32\%) and Anthocephalus cadamba Miq. (25.68\%). The diversity index for the study site was 2.56 which can be considered as moderate. Some of these trees are shown in Figure 2. along with their GPS coordinates.

List of species falling in the pole category and their important value index (IVI) is presented in Table 2. In pole category also, Swietenia mahagoni (L.) Jacq. has the highest IVI (51.30\%), followed by Lansium domesticum Corr. (47.36 \%) and Nephelium lappaceum Linn. (36.17\%) (Table 2). The value of the diversity index for the study site was 2.08 (classified as moderate). 17 species of medicinal herbs were found in USU Arboretum with a total of 1934 individuals. Solanum torvum Swartz. was the dominant species with 324 individuals in this area (Table 3). The diversity index for the study sites was 2.52 (classified as moderate). Species of medicinal plants in herb category, their numbers, and important value index is presented in Table 3 and some of these herbs are shown in Figure 3.

In herb category (Table 3), Melastoma candidum D. Don. has the highest IVI (35.76\%), followed by Clidemia hirta D. Don. (24.74\%) and Crassocephalum crepidioides (Benth.) S.Moore. (22.14\%). Solanum torvum Swartz. has the largest number of individuals in the study area because they grow wild and produce seeds in plenty. The value of the diversity index for the study sites was 2.52 (classified as moderate). This means that environmental conditions were relatively stable (Rahmawaty et al. 2017), meaning that the ecology of understorey vegetation was in a relatively stable condition (Hadi et al. 2016).

\section{Parts of plants utilized for medicinal}

The communities living around USU Arboretum have been using plants as medicine for a long time. This knowledge was transmitted from generation to generation. They use various parts of the plants, namely roots, stems, fruits, flowers, leaves, and rhizomes, as medicinal. Proportion of various medicinally useful parts of herbs, poles, and tree of USU Arboretum is shown in Figures 4 and 5 . 
Table 1. Species diversity, numbers of trees, important value index and species diversity index of medicinal plants of USU Arboretum, Deli Serdang District, North Sumatra, Indonesia

\begin{tabular}{|c|c|c|c|c|c|c|c|c|}
\hline $\begin{array}{c}\text { Local name } \\
\text { of species }\end{array}$ & Botanical name & $\begin{array}{c}\text { Botanical } \\
\text { families name }\end{array}$ & $\begin{array}{c}\text { Number of } \\
\text { trees }\end{array}$ & Rde & $\mathbf{R F}$ & Rdo & IVI (\%) & $\mathbf{H}^{\prime}$ \\
\hline Sentul & Sandoricum koetjape Merr. & Meliaceae & 21 & 3.95 & 3.96 & 5.69 & 13.60 & 0.11 \\
\hline Melinjo & Gnetum gnemon Linn. & Gnetaceae & 64 & 7.24 & 7.27 & 3.34 & 17.85 & 0.22 \\
\hline Saga & Adenanthera pavonina (L.) & Leguminosae & 27 & 7.89 & 7.93 & 4.67 & 20.49 & 0.13 \\
\hline Nangka & Artocarpus heterophyllus Lam. & Moraceae & 1 & 0.66 & 0.66 & 2.67 & 3.99 & 0.01 \\
\hline Matoa & Pometia pinnata J. R. Forst. \& G. Forst. & Sapindaceae & 15 & 5.26 & 5.28 & 3.09 & 13.63 & 0.09 \\
\hline Mindi & Melia azadirach $\mathrm{L}$. & Meliaceae & 36 & 7.24 & 7.27 & 3.99 & 18.50 & 0.16 \\
\hline Suren & Toona sinensis (Juss.) M.Roem & Meliaceae & 10 & 1.97 & 1.98 & 5.35 & 9.30 & 0.06 \\
\hline Jati & Tectona grandis Linn.F. & Verbanaceae & 33 & 4.61 & 4.62 & 6.50 & 15.73 & 0.15 \\
\hline Asam gelugur & Garcinia atroviridis Griff. ex T. Anders & Clusiaceae & 13 & 3.29 & 3.30 & 2.86 & 9.45 & 0.08 \\
\hline Kemiri & Aleurites moluccana (L.) Willd & Euphorbiaceae & 6 & 1.32 & 1.32 & 5.18 & 7.82 & 0.04 \\
\hline Pulai & Alstonia scholaris (L.) R.Br. & Apocynaceae & 89 & 8.55 & 8.59 & 12.18 & 29.32 & 0.27 \\
\hline Mahoni & Swietenia mahagoni (L.) Jacq. & Meliaceae & 146 & 14.47 & 14.53 & 4.88 & 33.89 & 0.33 \\
\hline Melina & Gmelina arborea Roxb. & Verbanaceae & 42 & 3.29 & 3.30 & 8.29 & 14.88 & 0.17 \\
\hline Ketapang & Terminalia catappa $\mathrm{L}$. & Combretaceae & 42 & 4.61 & 4.62 & 3.71 & 12.94 & 0.17 \\
\hline Rambutan & Nephelium lappaceum L. & Sapindaceae & 28 & 4.61 & 4.62 & 2.55 & 11.78 & 0.13 \\
\hline Durian & Durio ziberthinus Murr. & Bombacaceae & 31 & 5.92 & 5.95 & 5.13 & 17.00 & 0.14 \\
\hline Jabon & Anthocephalus cadamba Miq. & Rubiaceae & 51 & 9.87 & 9.91 & 5.90 & 25.68 & 0.20 \\
\hline Kayu manis & Cinnamomum verum J.Presl. & Lauraceae & 9 & 3.29 & 3.30 & 2.95 & 9.54 & 0.06 \\
\hline Alpukat & Persea americana Mill. & Lauraceae & 1 & 0.66 & 0.66 & 2.67 & 3.99 & 0.01 \\
\hline Duku & Lansium domesticum Corr. & Meliaceae & 1 & 0.66 & 0.66 & 2.19 & 3.50 & 0.01 \\
\hline Sukun & Artocarpus communis Forst. & Moraceae & 1 & 0.66 & 0.66 & 6.07 & 7.39 & 0.01 \\
\hline Total & & & 667 & 100 & 100 & 100 & 300 & 2.56 \\
\hline
\end{tabular}

Table 2. Species in pole category, their numbers and important value index.

\begin{tabular}{|c|c|c|c|c|c|c|c|c|}
\hline $\begin{array}{c}\text { Local name } \\
\text { of species }\end{array}$ & Botanical name & $\begin{array}{c}\text { Botanical } \\
\text { families name }\end{array}$ & $\begin{array}{l}\text { Number } \\
\text { of poles }\end{array}$ & Rde & $\mathbf{R F}$ & Rdo & IVI (\%) & $\mathbf{H}^{\prime}$ \\
\hline Mahoni & Swietenia mahagoni (L.) Jacq. & Meliaceae & 14 & 21.21 & 18.45 & 11.63 & 51.30 & 0.33 \\
\hline Melinjo & Gnetum gnemon Linn. & Gnetaceae & 3 & 4.55 & 7.91 & 9.44 & 21.89 & 0.14 \\
\hline Saga & Adenanthera pavonina (L.) & Leguminosae & 2 & 3.03 & 5.27 & 7.16 & 15.46 & 0.11 \\
\hline Jati & Tectona grandis Linn.F. & Verbanaceae & 1 & 1.52 & 2.64 & 14.93 & 19.08 & 0.06 \\
\hline Jabon & Anthocephalus cadamba Miq. & Rubiaceae & 2 & 3.03 & 5.27 & 10.36 & 18.66 & 0.11 \\
\hline Asam gelugur & Garcinia atroviridis Griff. ex T. Anders & Clusiaceae & 4 & 6.06 & 7.91 & 10.44 & 24.41 & 0.17 \\
\hline Matoa & Pometia pinnata J. R. Forst. \& G. Forst. & Sapindaceae & 1 & 1.52 & 2.64 & 7.31 & 11.46 & 0.06 \\
\hline Duku & Lansium domesticum Corr. & Meliaceae & 18 & 27.27 & 18.45 & 1.63 & 47.36 & 0.35 \\
\hline Rambutan & Nephelium lappaceum Linn. & Sapindaceae & 9 & 13.64 & 13.18 & 9.36 & 36.17 & 0.27 \\
\hline Mindi & Melia azadirach $\mathrm{L}$. & $\overline{\text { Meliaceae }}$ & 5 & 7.58 & 7.91 & 3.92 & 19.40 & 0.20 \\
\hline Pulai & Alstonia scholaris (L.) R.Br. & Apocynaceae & 3 & 1.52 & 2.64 & 5.62 & 9.77 & 0.06 \\
\hline Ketapang & Terminalia catappa $\mathrm{L}$. & Combretaceae & 6 & 9.09 & 7.91 & 8.21 & 25.21 & 0.22 \\
\hline Total & & & 68 & 100 & 100 & 100 & 300 & 2.08 \\
\hline
\end{tabular}

Note : Rde=relative density, $\mathrm{RF}=$ relative frequency, $\mathrm{Rdo}=$ relative dominance, $\mathrm{IVI}=$ important value index, $\mathrm{H}^{\prime}=$ species diversity index

Table 3. List of medicinal species in the herbs category, their numbers and important value index

\begin{tabular}{|c|c|c|c|c|c|c|c|}
\hline $\begin{array}{c}\text { Local name of } \\
\text { species }\end{array}$ & Botanical name & $\begin{array}{c}\text { Botanical families } \\
\text { name }\end{array}$ & $\begin{array}{c}\text { Number of } \\
\text { medicinal } \\
\text { plants }\end{array}$ & Rde & $\mathbf{R F}$ & $\begin{array}{l}\text { IVI } \\
(\%)\end{array}$ & $\mathbf{H}^{\prime}$ \\
\hline$\overline{\text { Ikausabi }}$ & Crassocephalum crepidioides (Benth.) S.Moore. & Asteraceae & 240 & 12.41 & 9.73 & 22.14 & 0.26 \\
\hline Rimbang & Solanum torvum Swartz. & Solanaceae & 324 & 16.75 & 19.01 & 35.76 & 0.30 \\
\hline Sambiloto & Andrographis paniculata (Burm. fil.) Nees. & Acanthaceae & 66 & 3.41 & 3.09 & 6.51 & 0.12 \\
\hline Meniran & Phyllanthus urinaria $\mathrm{L}$. & Phyllanthaceae & 15 & 0.78 & 0.88 & 1.66 & 0.04 \\
\hline Senduduk & Melastoma candidum D. Don. & Melastomataceae & 12 & 0.62 & 1.33 & 1.95 & 0.03 \\
\hline Tempuyung & Sonchus arvensis L. & Asteraceae & 95 & 4.91 & 3.98 & 8.89 & 0.15 \\
\hline Senduduk bulu & Clidemia hirta (L.) D. Don. & Melastomataceae & 239 & 12.36 & 12.38 & 24.74 & 0.26 \\
\hline Putri malu & Mimosa pudica L. & Fabaceae & 179 & 9.26 & 7.96 & 17.21 & 0.22 \\
\hline Duhuut belulang & Eleusine indica (L.) Gaertn. & Poaceae & 31 & 1.60 & 1.77 & 3.37 & 0.07 \\
\hline Alang alang & Imperata cylindrical (L.) Raeusch. & Poaceae & 103 & 5.33 & 3.98 & 9.30 & 0.16 \\
\hline Nanangkaan & Euphorbia hirta L. & Euphorbiaceae & 157 & 8.12 & 7.07 & 15.19 & 0.20 \\
\hline Paet paet & Tithonia diversifolia & Asteraceae & 84 & 4.34 & 3.98 & 8.32 & 0.14 \\
\hline Pegagan & Centella a siatica (Hemsl.) A. Gray. & Apiaceae & 23 & 1.19 & 2.65 & 3.84 & 0.05 \\
\hline Oma & Cyperus rotundus $\mathrm{L}$. & Cyperaceae & 119 & 6.15 & 5.31 & 11.46 & 0.17 \\
\hline Pungpulutan & Uruna lobata $\mathrm{L}$. & Malvaceae & 150 & 7.76 & 8.84 & 16.60 & 0.20 \\
\hline Keji beling & Plantago lagopus L. & Plantaginaceae & 85 & 4.40 & 6.19 & 10.58 & 0.14 \\
\hline Keladi & Caladium sp. & Araceae & 12 & 0.62 & 1.77 & 2.39 & 0.03 \\
\hline Total & & & 1934 & 100 & 100 & 200 & 2.52 \\
\hline
\end{tabular}

Note : Rde=relative density, $\mathrm{RF}=$ relative frequency, IVI = important value index, $\mathrm{H}^{\prime}=$ species diversity index 


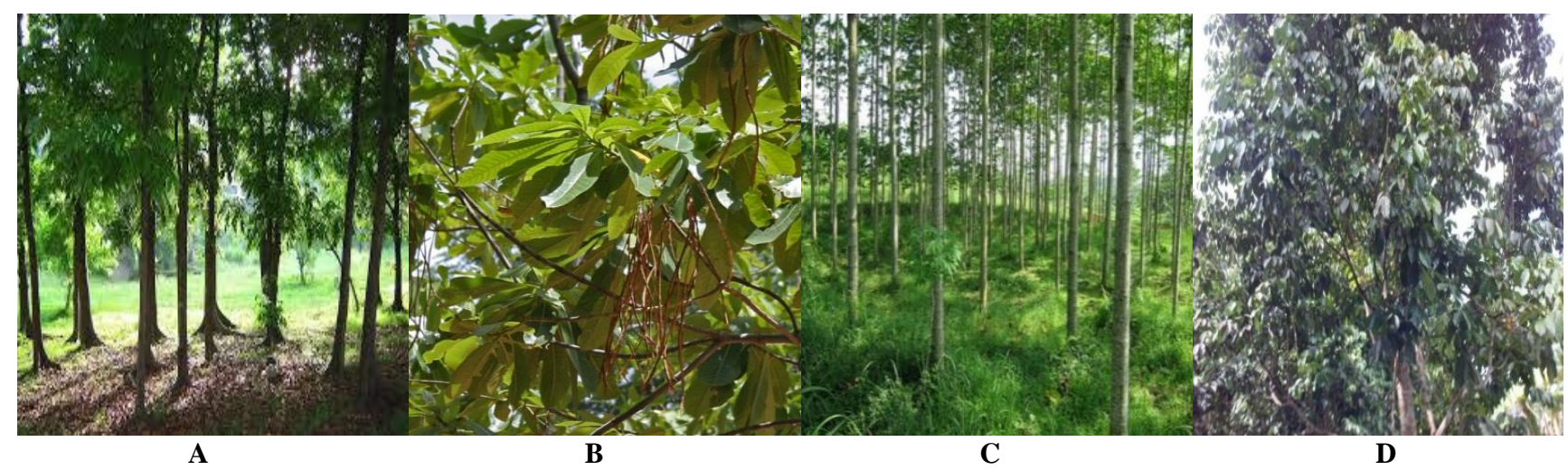

Figure 2. Some of the trees found at the USU Arboretum and their coordinate point: A. Swietenia mahagoni (L.) Jacq., B. Alstonia scholaris (L.) R.Br., C. Anthocephalus cadamba Miq., D. Lansium domesticum Corr.

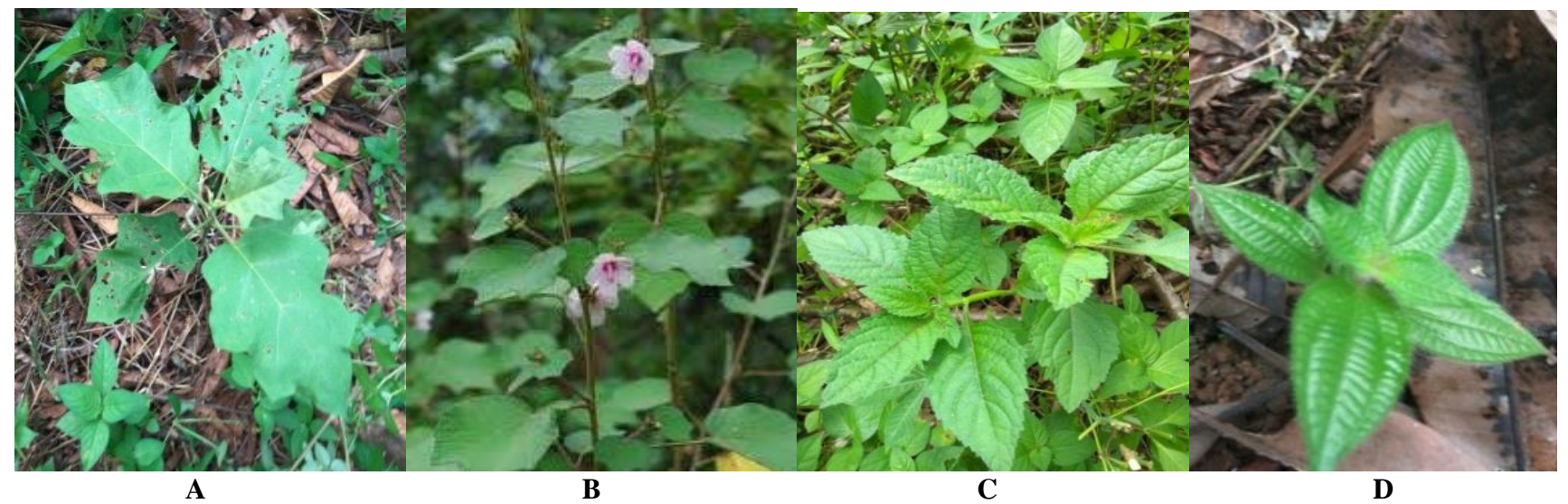

Figure 3. Medicinal herbs at the USU Arboretum, Deli Serdang District, North Sumatra, Indonesia, and their coordinate points: A. Solanum torvum Swartz., B. Uruna lobata L., C. Crassocephalum crepidioides (Benth.) S.Moore., D. Clidemia hirta (L.) D. Don.
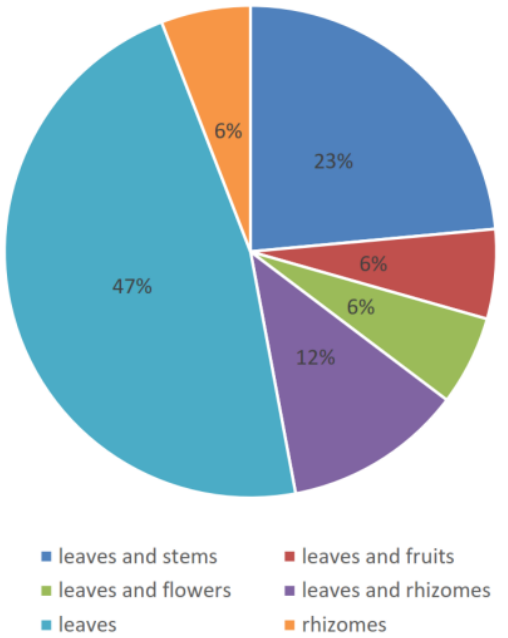

Figure 4. Percentage of medicinally useful parts of herbs of USU Arboretum, Deli Serdang District, North Sumatra, Indonesia
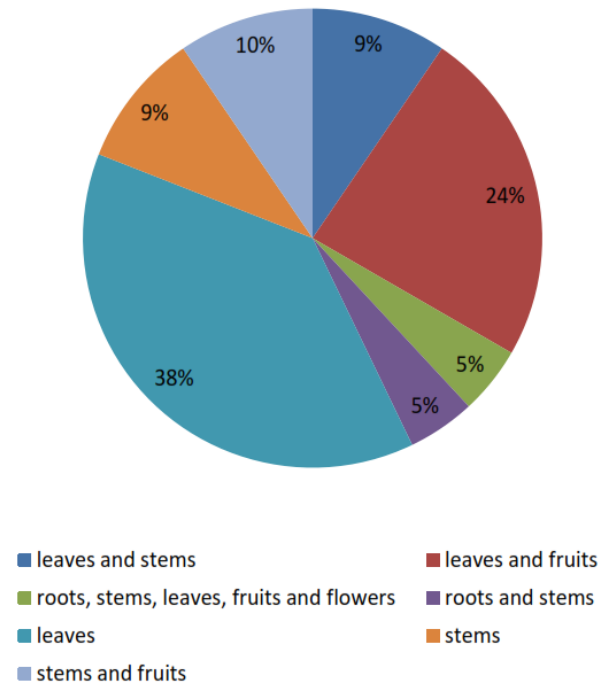

Figure 5. Percentage of medicinally useful parts of trees/poles of USU Arboretum, Deli Serdang District, North Sumatra, Indonesia 
Leaves were the most widely used plant part for medicinal purpose in herbs, poles, and trees (Figures 4 and 5 ). The community predominantly utilized leaves because there is a belief that certain plant leaves are having cooling property and, therefore, they can be used to treat fever and lower the patient's body temperature (Kala 2006, Zuhud and Hikmat 2009, Pandiangan et al. 2019). Some other tribes of Indonesia, such as the Simalungun Batak Tribe (Silalahi et al. 2015), the Karo Tribe (Purba et al. 2016), and the Sanger Tribe (Pandiangan et al. 2019), also utilize leaves as the predominant part for medicinal purpose, Silalahi et al. (2015) reported that the Simalungun Ethnic group used coarse-textured plant leaves to treat kidney disorders. The Sanger Tribe utilized leaves Orthosiphon spicatus and $S$. crispus to treat kidney disorders (Pandiangan et al. 2019).

Trees and poles found at the Arboretum USU and always used by the community as medicinal plants are Swietenia mahagoni (L.) Jacq., Alstonia scholaris (L.) R.Br., Lansium domesticum Corr., Anthocephalus cadamba Miq., Persea americana Mill., Garcinia atroviridis Griff. ex T. Anders., Terminalia catappa L. and Pometia pinnata . R. Forst. \& G. Forst. These plants were usually cultivated and commonly found in North Sumatra. Swietenia mahagoni (L.) Jacq. was used to reduce high blood pressure. Locals believe that drinking of water boiled with the seeds of Swietenia mahagoni (L.) Jacq. can reduce blood pressure. According to Nagalakshmi et al. (2001), the decoction of the bark of Swietenia mahagoni (L.) Jacq. is extensively used as febrifuge, which could be associated with its use as an antimalarial drug. Furthermore, Swietenia mahagoni (L.) Jacq. seeds have been employed in folk medicine for the treatment of hypertension, diabetes, and malaria. The seeds have also been reported to have therapeutic value in the treatment of cancer, amoebiasis, coughs, chest pains and intestinal parasitism (Sahgal et al. 2009).

Alstonia scholaris (L.) R.Br. leaves were used by local community for the treatment of fever and headache. Studies of Dalimantha (2008) and Pandiangan et al. (2019) have shown that, besides for the treatment of fever and headache, Alstonia scholaris (L.) R.Br. is also effective in the treatment of digestive disorders and malaria.

Use of Lansium domesticum Corr. by the local community was limited to consumption of the fruit. According to Dalimantha (2008) and Pandiangan et al. (2019), Lansium domesticum Corr. has anti-oxidants that may be useful in cancer treatment. Fruits are high in vitamin $\mathrm{C}$ which functions to maintain healthy gums and mouth.

Extract of Anthocephalus cadamba Miq. leaves were used by local community as a mouthwash. According to Duke (2010), various parts of this plant have traditionally been used as an antidiuretic, in the treatment of fever, anemia, and tumor, and for the improvement of semen quality. This plant was traditionally used in the form of a paste by a tribe in Western Ghats for treating skin diseases (Mishra and Siddique 2011). The bark extract has also been reported to be traditionally used as a hypoglycemic agent in Bangladesh (Ghani 2003).
The local communities use Garcinia atroviridis Griff. ex T. Anders. for hypertension. According to a previous study by Hamidon et al. (2017), G. atroviridis was also used as a traditional remedy for post-partum treatment. In addition, the leaves were used to treat high blood pressure and slimming.

Extract Solanum torvum Swartz. was used by the local community as a treatment for skin diseases. According to Jaiswal (2012) Solanum torvum Swartz. was found in tropical Africa, Asia, and South America. In several countries, Solanum torvum Swartz. was widely used as a vegetable and food ingredient. It has a wide spectrum of pharmacological activities, such as antimicrobial and antifungal (Balachandran et al. 2012), anti-inflammatory (Lee et al. 2013), antioxidant (Ramamurthy et al. 2012), antihelmintic (Kamaraj et al. 2011), antidiabetic (Gandhi et al. 2011a; Gandhi et al. 2011b) and nephroprotective activities (Mohan et al. 2010).

Urena lobata L. was used by local community as traditional medicine for treating rheumatism, to treat intestinal complaints, inflammation of the intestine, bladder, abdominal pain, diarrhea and dysentery (Babu et al. 2016). Furthermore, Babu et al. (2016) mentioned that, in India, extracts of leaves and roots are used in herbal medicine to treat such diverse ailments as colic, malaria, gonorrhea, toothache, fever, wounds, and rheumatism.

Leaves of Crassocephalum crepidioides (Benth.) S.Moore. were used by local community as medicine for boils. According to Musa et al. (2011), the plant was known to contain a large number of phytochemical compounds, namely tannin, dihydroisocoumarins, pyrrolizidine alkaloids, and monoterpenes. In Southern Nigeria, this plant was used for treatment of indigestion, in Congo for treatment of stomach upset, and in Uganda for treatment of fresh wounds. The decoction of the leaf was used in Nigeria for the treatment of headache. In Tanzania, a mixture of the leaf sap of Crassocephalum crepidioides and Cymbopogon giganteus was used orally and externally for the treatment of epilepsy. In Tanzania, the dried leaf powder was applied as a snuff to stop nose bleeding and it is also smoked to cure sleeping sickness. Tannins found in the roots of the plant was used to treat swollen lips.

Clidemia hirta (L.) D. Don. was used by local community as a wound healer. According to Dalimartha (2008), it has active substances, namely flavonoids, steroids, saponins, and tannins and therefore can be used as a wound healer.

According to Zein (2005), in the past, medicinal plants played an important role, due to the non-availability of modern health facilities, especially in remote areas. Medicinal plants are still widely used by people in traditional medicinal practices and are playing a very important role in the area of global health management. Abdiyani (2008) stated that the treatment using traditional herbs has advantages in general and is considered safer than the use of modern medicine because traditional medicine has relatively fewer side effects than modern medicine. Based on WHO, IUCN and WWF records, more than 20,000 species of medicinal plants were used by $80 \%$ of the population worldwide. Research reports and 
literature indicate that not less than 2039 species of medicinal plants originate from Indonesian forests (Zuhud 2009).

\section{Distribution of medicinal plants}

Distribution maps for the medicinal trees, poles, and herbs in the arboretum is shown in Figures 6 and 7. These maps indicate the geographical location of medicinal plants in USU Arboretum. Trees were planted almost at the same time. Hence, the distribution of medicinal plants in USU Arboretum is mostly clustered and uneven. According to Kala (2006), plant species were rarely uniformly distributed. The distribution of medicinal plants varies in each location as shown by Al-Bakri (2011), Vidyarthi et al. (2013), Mashayekhan (2016) and Biswas (2017). Several seedlings were obtained from the Wampu Sei Ular Watershed Management Office. The opening of the road in the arboretum caused some of the trees in the arboretum to be lost/cut down (Figure 1). Medicinal herbs that were found in USU Arboretum grow wild, as reported earlier by Mashayekhan (2016).
The information from the maps clarifies the current situation of medicinal species distribution in USU Arboretum. The maps of species distribution are helpful to conservation. The map indicates that additional medicinal trees can be planted in the western and the northern part of USU Arboretum. For tree planting and cultivation activities at the USU Arboretum, promoting the role and participation of stakeholders, especially the local community is important. According to Rahmawaty et al. (2011), participatory management by involving stakeholders can be effective. The communities and other stakeholders will also maintain and preserve the USU Arboretum if they are involved. Thus, the USU Arboretum can be preserved sustainably.

In conclusion, the diversity of vegetation condition was moderate. The most dominant part of plant utilized for medicinal were leaves. The use of medicinal plants at the USU Arboretum by local community still limited to personal medical needs. Planting tree species in USU Arboretum is still needed especially in the western part and the northern part.
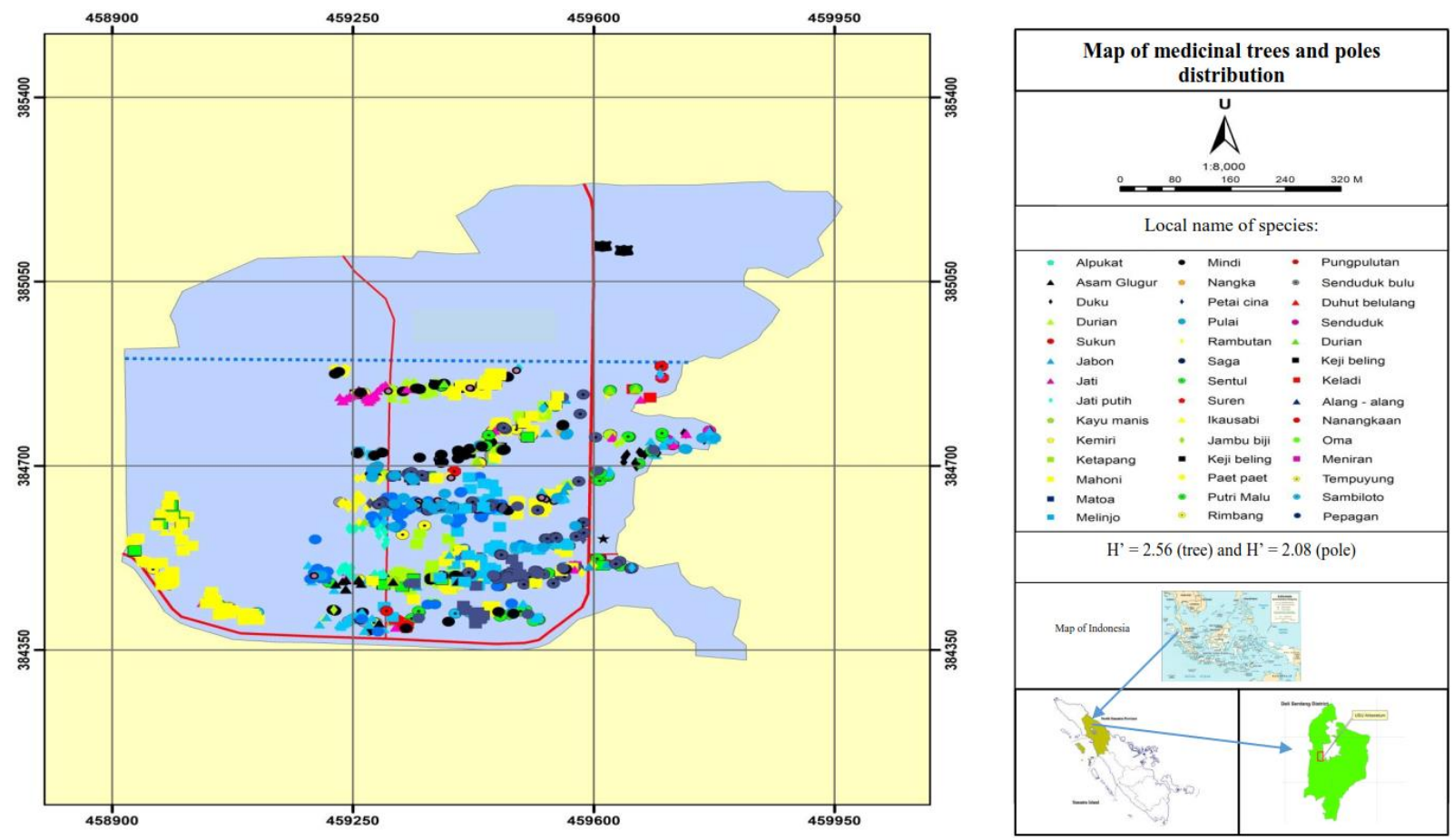

Figure 6. Distribution map of medicinal trees and poles in USU Arboretum, Deli Serdang District, North Sumatra, Indonesia 

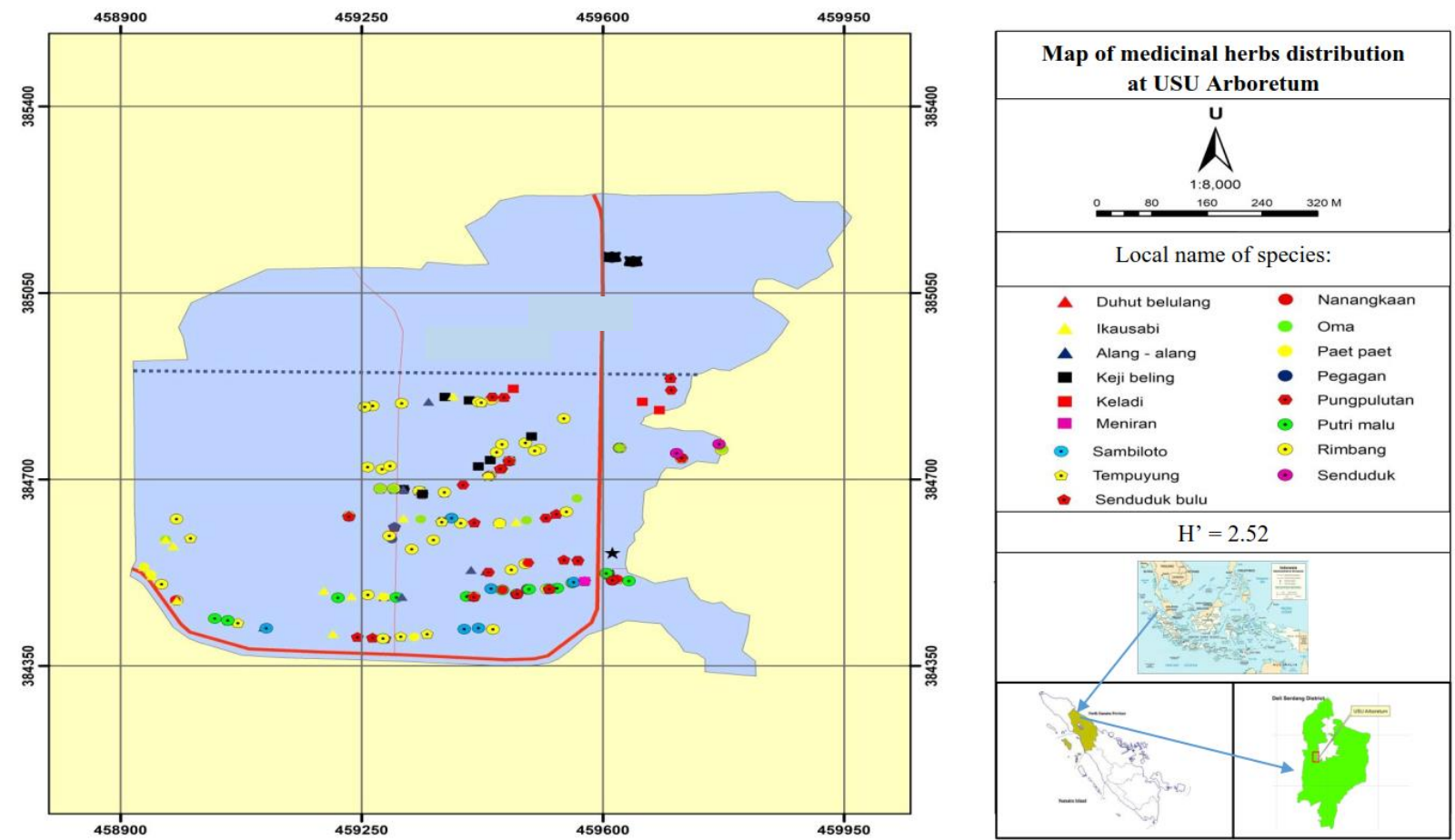

Figure 7. Distribution map for medicinal herbs in USU Arboretum, Deli Serdang District, North Sumatra, Indonesia

\section{ACKNOWLEDGMENTS}

This work was part of a research project about mapping of medicinal plants distribution in North Sumatra, funded by grant "Talenta" USU 2018 No. 2590/UN5.1.R/PPM/2018. We thank the organizing committee of the International Conference on Sustainable Agriculture and Natural Resources Management 2018, for supporting the presentation of this work on 28 August 2018, at the Garuda Plaza Hotel, Medan. We also thank the students of the Faculty of Forestry, USU (especially Kristo, Agung, Herbeth, Juan, and Tike) who assisted with fieldwork. We also thank the editor and anonymous reviewers for their constructive comment/suggestion on the manuscript.

\section{REFERENCES}

Aliabad FA, Shojaei S, Zare M, Ekhtesasi MR. 2018. Assessment of the fuzzy ARTMAP neural network method performance in geological mapping using satellite images and Boolean logic. Intll J Environ Sci Technol. DOI: 10.1007/s13762-018-1795-7.

Al-Bakri JT, Al-Eisawi D, Damhoureyeh S, Oran S. 2011. GIS-based analysis of spatial distribution of medicinal and herbal plants in arid and semi-arid zones in the Northwest of Jordan. Ann Arid Zone 50 (2): 99-115.

Babu SS, Madhuri DB, Ali SL. 2016. A Pharmacological review of Urena lobata plant. Asian J Pharm Clin Res 9 (2): 20-22.

Balachandran C, Duraipandiyan V, Al-Dhabi NA, Balakrishna K, Kalia NP, Rajput VS. 2012. Antimicrobial and antimycobacterial activities of methyl caffeate isolated from Solanum torvum Swartz. fruit. Indian J Microbiol 52: 676-81.

Balai Pustaka. 1980. Medicinal Plants. Balai Pustaka, Jakarta. [Indonesia]
Biswas B, Walker S, Varun M. 2017. Web GIS-based identification and mapping of medicinal plants: a case study of Agra (u.p.), India. Plant Arch 17 (1): 8-20.

Chowdhury MSH, Koike M, Muhammed N, Halim MA, Saha N, Kobayashi H. 2009. Use of plants in healthcare: a traditional ethnomedicinal practice in rural areas of southeastern Bangladesh. Intl J Biodivers Sci Manag 5 (1): 41-51.

Dalimartha S. 2008. Atlas of Indonesian plant IX. Penerbit Pustaka Pembangunan Swadaya Nusantara, Jakarta. [Indonesian]

Deb D, Datta BK, Debbarma J, Deb S. 2016. Ethno-medicinal plants used for herbal medication of jaundice by the indigenous community of Tripura, India. Biodiversitas 17 (1): 256-269.

Duke. 2010. Phytochemical and Ethnobotanical Database 2010. ARS, National Genetic Resources Program. Germplasm Resources Information Network (GRIN). National Germplasm Resources Laboratory, Beltsville, Maryland.

Fathizad H, Pakbaz N, Sodaiezadeh H, Shojaei S. 2017. Exploring canola planting area using AHP associated with GIS in Meymeh-Zarinabad of Iran. Spat Inf Res 25 (3): 371-379.

Gandhi GR, Ignacimuthu S, Paulraj MG. 2011a. Solanum torvum Swartz. fruit containing phenolic compounds shows antidiabetic and antioxidant effects in streptozotocin-induced diabetic rats. Food Chem Toxicol 49: 25-33.

Gandhi GR, Ignacimuthu S, Paulraj MG, Sasikumar P. 2011 b. Antihyperglycemic activity and antidiabetic effect of methyl caffeate isolated from Solanum torvum Swartz. fruit in streptozotocin-induced diabetic rats. Eur J Pharmacol 67 (6): 23-31

Ghani A. 2003. Medicinal Plant of Bangladesh with Chemical Constituents and Uses. 2nd ed. Asiatic Society of Bangladesh, Dhaka. Hamidon H, Susanti D, Taher M, Zakaria ZA. 2017. Garcinia atroviridisa review on phytochemicals and pharmacological properties. Marmara Pharm J 21: 38-47.

Hamidy N, Alipur H, Nasab SNH, Yazdani A, Shojaei S. 2016. Spatial evaluation of appropriate areas to collect runoff using Analytic Hierarchy Process (AHP) and Geographical Information System (GIS) (case study: the catchment "Kasef" in Bardaskan. Modeling Earth Syst Environ 2 (4): 1-11.

Hutapea JR, Soeharso, Sutjipto, Djumidi S, Sugeng W, Yuli, Sihotong. 1994. Indonesian Medicinal Inventory. Volume III. Ministry of Health Republic of Indonesia, Jakarta. [Indonesian] 
Jaiswal BS. 2012. Solanum torvum: A review of its traditional uses, phytochemistry, and pharmacology. Intl J Pharm Biol Sci 3 (4): 104111.

Kala CP. 2006. Medicinal plants of the high altitude cold desert in India: diversity, distribution and traditional uses International. J Biodivers Sci Manag 2: 43-56.

Kamaraj C, Rahuman AA, Elango G, Bagavan A, Zahir AA. 2011. Anthelmintic activity of botanical extracts against sheep gastrointestinal nematodes, Haemonchus contortus. Parasitol Res 109: $37-45$.

Kent M, Paddy C. 1992. Vegetation description and analysis of a practical approach. Belhaven Press, London.

Lee CL, Hwang TL, He WJ, Tsai YH, Yen CT, Yen HF. 2013. Antineutrophilic inflammatory steroidal glycosides from Solanum torvum. Phytochemistry 95: 315-21.

Lense O. 2012. The wild plants used as traditional medicines by indigenous people of Manokwari, West Papua. Biodiversitas 13 (2): 98-106.

Mashayekhan A, Pourmajidian MR, Vand HJ, Gholami MR, Teimouri MS. 2016. Economic importance and GIS mapping of medicinal plants in Iran: A case study of Darkesh. J Appl Sci Environ Manag 20 (3): 646-650

Misra R. 1968. Ecology Work Book. Oxford and IBH, Calcutta.

Mohan M, Kamble S, Gadhi P, Kasture S. 2010. Protective effect of Solanum torvum on doxorubicin-induced nephrotoxicity in rats. Food Chem Toxicol 48: 436-440.

Musa AA, Adekomi DA, Tijani AA, Muhammed OA. 2011. Some of the effect of crassocephalum crepidioides on the frontal cortex, kidney, liver and testis of adult male Sprague Dawley rats: microanatomical study. Eur J Exp Biol 1 (3): 228-235.

Musinguzi D, Tumushabe A, Sekabira K, Basamba TA, Byarugaba D. 2017. Medicinal plants use in and around Kalinzu central forest reserve, Western Uganda. J Med Plant Stud 5 (6): 44-49.

Nagalakshmi MAH, Thangadurai D, Muralidara D, Pullaiah RT. 2001. Phytochemical and antimicrobial study of Chukrasia tabularis leaves. Fitoterapia 72: 62-64

Noorul H, Nesar A, Zafar K, Khalid M, Zeeshan A, Vartika S. 2016 Health benefits and pharmacology of Persea americana Mill. (avocado). Intl J Res Pharmacol Pharmacotherapeut 5 (1): 132-141.

Nugroho IA. 2010. National workshop on Indonesian medicinal plant. The Asian Pacific forest genetic resources program collaborates with the research and development center for increasing forest productivity. Apforgen News Lett 2 (2): 1-2. [Indonesian]

Pandiangan D, Silalahi M, Dapas F, Kandou F. 2019. Diversity of medicinal plants and their uses by the Sanger Tribe of Sangihe Islands, North Sulawesi, Indonesia. Biodiversitas 20: 621-631.

Piri I, Moosavi M, Taheri AZ, Alipur H, Shojaei S, Mousavi SA. 2019. The spatial assessment of suitable areas for medicinal species of Astragalus (Astragalus hypsogeton Bunge) using the Analytic Hierarchy Process (AHP) and Geographic Information System (GIS) Egypt J Rem Sens Space Sci. DOI: 10.1016/j.ejrs.2018.02.003

Purba EC, Nisyawati, Silalahi M. 2016. The ethnomedicine of the Batak Karo peoples of Merdeka Subdistrict, North Sumatra, Indonesia. Intl J Biol Res 4 (2): 181-189.

Rahmawaty, Villanueva TR, Carandang MG. 2011. Participatory land use allocation, case study in Besitang Watershed, Langkat North Sumatra, Indonesia. Lambert Academic Publishing, Germany.
Rahmawaty, Sari EK, Syofyan A, Rauf A. 2015. Integrated geographic information system and global positioning system for mapping of forest plants in supporting natural resources protection. Procedia Chem 14: 334-342.

Rahmawaty, Sitorus NA, Rauf A. 2017a. Distribution, above-ground biomass and carbon stock of the vegetation in Taman Beringin urban forest. Medan City, North Sumatra Indonesia. Malaysian For 80 (1): 73-84.

Rahmawaty, Patana P, Latifah S. 2017b. Spatial analysis on distribution of green belt to reduce impacts of climate change in Medan City, North Sumatra. Malaysia Appl Biol J 46 (2): 67-76.

Rahmawaty, Sembiring IEP, Batubara R, Patana P. 2018. Mapping of tree damage classification in the western part of Medan City green belts using geographic information system. IOP Conf Ser: Earth Environ Sci 166 (1): 12020. DOI: 10.1088/1755-1315/166/1/012020

Ramamurthy $\mathrm{CH}$, Kumar MS, Suyavaran VS, Mareeswaran R, Thirunavukkarasu C. 2012. Evaluation of antioxidant, radical scavenging activity and polyphenolics profile in Solanum torvum L. fruits. J Food Sci 77: 7-13.

Sahgal G, Ramanathan S, Sasidharan S, Mordi MN, Ismail S, Mansor SM. 2009. Phytochemical and antimicrobial activity of Swietenia mahagoni crude methanolic seed extract. Tropical Biomedicine 26 (3): 274-279

Shannon CE, Wiener W. 1963. The mathematical theory of communication. University of Juionis Press, Urbana, IL.

Sharma PD. 2003. Ecology and Environment. 7th ed. Rastogi Publication, New Delhi.

Shojaei S, Alipur H, Ardakani AHH, Nasab SNH, Khosravi H. 2018. Locating Astragalus hypsogeton Bunge appropriate site using AHP and GIS. Spat Inf Res 26 (2): 223-231.

Silalahi M, Nisyawati, Walujo EB, Supriatna J, Mangunwardoyo W. 2015. The local knowledge of medicinal plants trader and diversity of medicinal plants in the Kabanjahe traditional market, North Sumatra, Indonesia. J Ethnopharmacol 175: 432-443.

Singh A, Lal M, Samant SS. 2009. Diversity, indigenous uses and conservation prioritization of medicinal plants in Lahaul valley, proposed cold desert biosphere reserve, India. Intl J Biodivers Sci Manag 5 (3): 132-154.

Vidyarthi S, Samant SS, Sharma P. 2013. Traditional and indigenous uses of medicinal plants by local residents in Himachal Pradesh, North Western Himalaya, India. Intl J Biodivers Sci: Ecosyst Serv Manag 9 (3): 185-200.

Zarta AR, Ariyani F, Suwinarti W, Kusuma IW, Arung ET. 2018. Short communication: identification and evaluation of bioactivity in forest plants used for medicinal purposes by the Kutai community of East Kalimantan, Indonesia. Biodiversitas 19 (1): 253-259.

Zuhud EAM. 2009. The potential of Indonesian tropical forests as a support for natural medicines for national health. http: //www. researchgate.net./publication/267857735.

Zuhud EAM, Hikmat A. 2009. Indonesian tropical forest as a warehouse for natural medicine for the nation's independent health. Research and Development Center for Forest Crops, Bogor.

Zuhud EAM, Sambas B, Rinekso S. Ekarelawan, Erna S. 1994 Development and research program for medicinal plants in Indonesia. Proceedings of the Preservation Seminar on the Utilization of Diversity of Indonesian Tropical Forest Medicinal Plants. Faculty of Forestry IPB and LATIN, Bogor. [Indonesian] 